OPEN ACCESS

Edited by:

Andrew Morris,

University of Liverpool,

United Kingdom

Reviewed by:

Alexandre Rezende Vieira, University of Pittsburgh,

United States

Marika Kaakinen,

University of Surrey, United Kingdom

${ }^{*}$ Correspondence:

Xian-Tao Zeng

zengxiantao1128@163.com

Pei-Liang Geng

medchn@qq.com

Specialty section:

This article was submitted to

Genetic Disorders,

a section of the journal

Frontiers in Genetics

Received: 19 March 2019

Accepted: 03 July 2019

Published: 05 August 2019

Citation:

Wu L, Deng T, Wang C-Y, Ren X-Q,

Wang $Y-Y$, Zeng $X-T$ and Geng $P-L$

(2019) Serotonin Transporter

(5-HTT) Gene Polymorphisms

and Susceptibility to Chronic

Periodontitis: A Case-Control Study.

Front. Genet. 10:706.

doi: 10.3389/fgene.2019.00706

\section{Serotonin Transporter (5-HTT) Gene Polymorphisms and Susceptibility to Chronic Periodontitis: A Case- Control Study}

\author{
Lan $\mathrm{Wu}^{1,2}$, Tong Deng ${ }^{1,3}$, Chao-Yang Wang ${ }^{3}$, Xue-Qun Ren ${ }^{3}$, Yun-Yun Wang ${ }^{1}$, \\ Xian-Tao Zeng ${ }^{1,2 *}$ and Pei-Liang Geng ${ }^{1,3^{*}}$ \\ ${ }^{1}$ Center for Evidence-Based and Translational Medicine, Zhongnan Hospital of Wuhan University, Wuhan, China, \\ 2 Department of Stomatology, Zhongnan Hospital of Wuhan University, Wuhan, China, ${ }^{3}$ Center for Evidence-Based \\ Medicine, Institute of Evidence-Based Medicine and Knowledge Translation, Henan University, Kaifeng, China
}

Objective: The current study is aimed at exploring the relationship between chronic periodontitis and serotonin transporter (5-HTT) gene polymorphisms (rs6354 and rs12449783) in the Chinese Han population.

Methods: This study included a total of 120 patients with chronic periodontitis and 125 healthy control subjects. The 5-HTT gene (rs6354 and rs12449783) was genotyped using oral mucosal tissue with a polymerase chain reaction-restriction fragment length polymorphism (PCR-RFLP). Linkage disequilibrium was examined using Haploview. Genotype and allele frequencies were compared between the cases and controls using a $\chi^{2}$ test.

Results: Genotype distribution of the 5-HTT gene polymorphisms rs6354 and rs12449783 in the control group conformed to Hardy-Weinberg equilibrium. The frequency of the AC genotype, the $A C+C C$ genotype and $C$ allele of the 5-HTT rs6354 polymorphism was higher in cases $(P<0.05)$ vs. the healthy control. The adjusted odds ratio $(\mathrm{OR})$ was $1.910(95 \% \mathrm{Cl}=1.049-3.476)$ for the AC genotype, $2.026(95 \% \mathrm{Cl}=1.115-3.680)$ for the $\mathrm{AC}+\mathrm{CC}$ genotype, and 1.875 for the $\mathrm{C}$ allele $(95 \% \mathrm{Cl}=1.089-3.228$. Such an association was particularly strong in women for the AC genotype $(\mathrm{OR}=2.167,95 \% \mathrm{Cl}=$ 1.034-4.542). The genotype and allele frequencies of rs12449783 did not differ between the cases and controls. Haplotype C-C (rs6354-rs12449783) was also more frequent in the cases $(\mathrm{OR}=2.372,95 \% \mathrm{Cl}=1.154-4.875, \mathrm{P}=0.016)$.

Conclusion: Chronic periodontitis is associated with the 5-HTT gene rs6354 polymorphism, as well as rs6354/rs12449783 interaction.

Keywords: 5-HTT, polymorphism, chronic periodontitis, PCR-RFLP, case-control study

\section{INTRODUCTION}

Periodontal diseases are a set of highly prevalent inflammatory diseases that affect the tissues (gingiva, periodontal ligaments and alveolar bone) that support the teeth (Carinci et al., 2013). In the early stage of gingivitis, only the gums are affected. In the late stage of chronic periodontitis, bone loss occurs. Genetic, environmental, and behavioral factors contribute to the development of periodontal 
diseases (Meyle and Chapple, 2015; Lee et al., 2015; Silva et al., 2015; Thyvalikakath et al., 2015; Fann et al., 2016). Periodontal diseases could produce a reciprocal impact on general health and other organ systems, and may contribute to the development and progression of diabetes, cardiovascular diseases, gastrointestinal tract diseases, and kidney diseases (Bansal et al., 2013; Nagpal et al., 2015; Carrizales-Sepulveda et al., 2018).

5-hydroxytryptamine (5-HT) is a monoamine neurotransmitter that regulates the function of the central nervous system (Ma et al., 2015) as well as other physiological processes (Chilmonczyk et al., 2015). Re-uptake by the 5-HT transporter (5-HTT or SLC6A4) is a major mechanism that removes 5-HT from the synaptic cleft after release. The human gene is located on chromosome $17 \mathrm{q} 11.2$ and consists of 15 exons. The gene occurs in polymorphic forms, which in turn affects 5-HTT expression levels, and ultimately 5-HT concentration (Ho et al., 2013).

The 5-HTT gene is implicated in complex behavioral traits and a variety of psychiatric diseases (Defrancesco et al., 2013; Cengiz et al., 2015; Tollenaar et al., 2017). Several previous studies associate periodontal diseases with psychological stress and anxiety (Goyal et al., 2013; Graetz et al., 2013; Reshma et al., 2013; Delgado-Angulo et al., 2015). Periodontal disease occurrence is affected by both genetic and environmental factors (Slayton, 2006; Jin et al., 2011; Divaris et al., 2013). 5-HT is also implicated in bone metabolism (Feuer et al., 2015), and could control periodontitis-induced alveolar bone loss (Galli et al., 2013). We therefore speculate that 5-HT neurotransmission is implicated in periodontal diseases and thus conducted a casecontrol study to examine the potential association between chronic periodontitis with single nucleotide polymorphisms (SNPs) (rs6354 and rs12449783) of the 5-HTT gene.

\section{MATERIALS AND METHODS}

\section{Study Subjects}

This study was approved by the Ethics Committee of the Institute of Evidence-Based Medicine and Knowledge Translation, Henan University. Sample collection conformed to the ethics criteria of national human genome research. All subjects provided written informed consent prior to study commencement.

This study included a total of 120 patients with chronic periodontitis (68 women and 52 men; age range: 36 to 57 years) receiving medical care as outpatients at Henan University Hospital during a period from July 2013 to July 2015. Subjects with diabetes or cardiovascular diseases were excluded. The diagnosis was established by the same dentist using the 1999 International Classification of the Periodontal Disease and Conditions (Armitage, 1999). The controls included 125 healthy individuals (72 women and 53 men, aged range: 33 to 64 years) receiving an annual physical check-up at Henan University Hospital during the same period. Controls had no oral diseases, systemic diseases or history of periodontal disease treatment. One-hundred-and-twenty-five healthy individuals (72 women and 53 men, aged between 33 and 64) were included. Both patients and the control subjects received a complete intra-oral examination to assess supra-gingival plaque accumulation, gingival recession, bleeding on probing (BOP), probing pocket depth (PPD), and clinical attachment loss (CAL). Specific criteria for chronic periodontitis included: $\mathrm{PPD}>5 \mathrm{~mm}$, $\mathrm{CAL}>4 \mathrm{~mm}$, gingival recession and tooth mobility. Control subjects had no gingival recession, $\mathrm{CAL}$ or $\mathrm{PPD}>3 \mathrm{~mm}$.

\section{Sample Collection}

Oral mucosa was obtained using a sterile dentiscalprum and stored at $-20^{\circ} \mathrm{C}$ prior to genomic DNA extraction using a phenolchloroform method.

\section{Genotyping}

Primers were designed with Primer Premier 5.0, and synthesized by Sangon Biotech (Shanghai, China) (Table 1). PCR amplification was performed in a total volume of $25 \mu \mathrm{l}$ with an ice bath, including $5 \mu \mathrm{l} 10 \times$ Buffer, $2 \mu \mathrm{l}$ template DNA, $1 \mu \mathrm{l}$ upstream primer, $1 \mu \mathrm{l}$ downstream primer, $0.5 \mu \mathrm{l}$ Taq DNA polymerase, $2 \mu \mathrm{dNTP}$, and $13.5 \mu$ deionized sterile water. The quality of the PCR products was examined using $1 \%$ agarose gel electrophoresis.

PCR products were digested at $37^{\circ} \mathrm{C}$ overnight with $\mathrm{HpaII}$ (rs6354) and MluCI (rs12449783), respectively. A total volume of $10 \mu \mathrm{l}$ digestion system contained $2 \mu \mathrm{l} 10 \times$ Buffer, $0.2 \mu \mathrm{l} 100 \times$ BSA, $0.5 \mu \mathrm{l}$ enzyme, $5 \mu \mathrm{l}$ PCR products, and $2.3 \mu \mathrm{l}$ deionized sterile water. DNA fragments were separated using $2 \%$ agarose gel electrophoresis and visualized under UV light.

\section{Statistical Analysis}

All statistical analyses were conducted using PASW statistics 18.0 software. Conformity of genotype distribution to Hardy-Weinberg equilibrium (HWE) was examined in the controls with Haploview. A $\chi^{2}$ test was used to compare genotype and allele distribution between the cases and controls. Association of 5-HTT gene polymorphisms with chronic periodontitis is presented as odds ratios (ORs) and 95\% confidence intervals (CIs), and adjusted for age, sex and smoking status. A subgroup analysis was performed based on sex. Statistical significance was set at $\mathrm{P}<0.05$ (two-sided).

\section{RESULTS}

\section{Demographic and Clinical Characteristics}

The obtained 120 patients included 68 women and 52 men with an age range from 36 to 57 . And the mean age of the patients and controls was $45.32 \pm 10.59$ and $46.51 \pm 11.86$ years, respectively (Table 2). The female to male ratio was 1.31 and 1.36 in the cases and controls, respectively. More subjects were smokers in the cases than in controls $(P=0.001)$.

TABLE 1 | Primer sequences for 5-HTT gene rs6354 and rs12449783 polymorphisms.

\begin{tabular}{lll}
\hline SNP & Primer sequence & \\
\hline rs6354 & Upstream & 5'-CCTGCACACTCTTCTCCCTA-3' \\
& Downstream & 5'-TTCTGCGTTCCCATTATGC-3' \\
rs12449783 & Upstream & $5^{\prime}$-AGTAAGCGGTGGCTCACTCC-3' \\
& Downstream & $5^{\prime}$-TGCCCATGTGCATGTTAAT-3'
\end{tabular}


TABLE 2 | Demographic and clinical characteristics of the cases and controls.

\begin{tabular}{lccc}
\hline & Case $(\boldsymbol{n}=\mathbf{1 2 0})$ & Control $(\boldsymbol{n}=\mathbf{1 2 5})$ & $\boldsymbol{P}$ \\
\hline Age (year) & $45.32 \pm 10.59$ & $46.51 \pm 11.86$ & 0.463 \\
Gender (\%) & & & 0.883 \\
Male & $52(43.33)$ & $53(42.40)$ & \\
Female & $68(56.67)$ & $72(57.60)$ & \\
Smoking (\%) & & & 0.001 \\
Current and ever & $41(34.17)$ & $19(15.20)$ & \\
Never & $79(65.83)$ & $47.96 \pm(84.80)$ & \\
BOP (\% site) & $83.55 \pm 19.64$ & $1.59 \pm 0.48$ & $<0.001$ \\
PPD (mm) & $5.86 \pm 0.67$ & 0.0 & $<0.001$ \\
CAL (mm) & $6.32 \pm 0.81$ & 0.01
\end{tabular}

$B O P$, bleeding on probing; $P P D$, probing pocket depth; $C A L$, clinical attachment loss.

\section{HWE Test}

Genotype distribution of the gene polymorphisms rs6354 and rs12449783 in the control group conformed to HWE $(P>0.05$, Table 3).

\section{Genotype and Allele Distributions}

The CC genotype of rs6354 was not detected in the healthy controls, and in only $1(0.83 \%)$ of the cases (Table 3 and Figure 1$)$. The frequency of the AA genotype of rs6354 did not differ between the cases and controls (67.50\% vs. $79.20 \%)$. The frequency AC genotype of rs6354 was significantly higher in the cases ( $31.67 \%$ vs. $20.80 \%$ in the controls; $P=0.048)$. OR was 1.786 (95\% CI $=1.001-3.187)$. An analysis using the dominant model revealed a higher $\mathrm{AC}+\mathrm{CC}$ genotype frequency in the cases $(\mathrm{OR}=1.833,95 \% \mathrm{CI}=1.030-3.263, P=0.038)$. After adjustment for age, sex and smoking, the association remained significant (AC vs. AA: adjusted OR $=1.910,95 \% \mathrm{CI}=1.049-3.476$,
$P=0.034 ;$ AC+CC: adjusted $\mathrm{OR}=2.026,95 \% \mathrm{CI}=1.115-3.680, P=$ $0.016)$. The $\mathrm{C}$ allele frequency was higher in the cases $(16.67 \%$ vs. $10.40 \% ; \mathrm{P}=0.042)$, with an $\mathrm{OR}$ at $1.723(95 \% \mathrm{CI}=1.015-2.925)$. The results were similar after adjustment for clinical parameters (adjusted $\mathrm{OR}=1.875,95 \% \mathrm{CI}=1.089-3.228, P=0.023$ ).

The rs12449783 genotype did not differ between the cases and controls (Table 3): $8.33 \%$ vs. $5.60 \%$ for AA, $30.00 \%$ vs. $34.40 \%$ for $\mathrm{AC}$, and $61.67 \%$ vs. $60.00 \%$ for CC.

The subgroup analysis that included only women showed a higher frequency of the AC genotype of rs6354 in the cases (38.24\% vs. $22.22 \%, P=0.039)$, with an $\mathrm{OR}$ at $2.167(95 \% \mathrm{CI}=$ 1.034-4.542) (Figure 2 and Table 4). No difference was detected between the cases and the controls in the male population in both rs6354 and rs12449783 (Figure 2 and Table 4).

\section{The LD Analysis of rs6354 and rs12449783}

Significant LD of rs6354 and rs12449783 was identified (D' $=0.71$, $\mathrm{r} 2=0.331)$. The $\mathrm{C}-\mathrm{C}$ haplotype was associated with periodontitis $(\mathrm{OR}=2.372,95 \% \mathrm{CI}=1.154-4.875, P=0.016)$. Detailed haplotype information is shown in Table 5.

\section{DISCUSSION}

Periodontal diseases contribute to the development and progression of many other diseases (Nagpal et al., 2015). The importance of prevention, early diagnosis and treatment of periodontal diseases is thus far beyond the scope of dentistry.

Many factors, including oral hygiene, smoking, stress and anxiety, obesity and diabetes, contribute to the etiology of periodontal

TABLE 3 | Genotype and allele distributions of rs6354 and rs12449783 polymorphisms in the cases and controls.

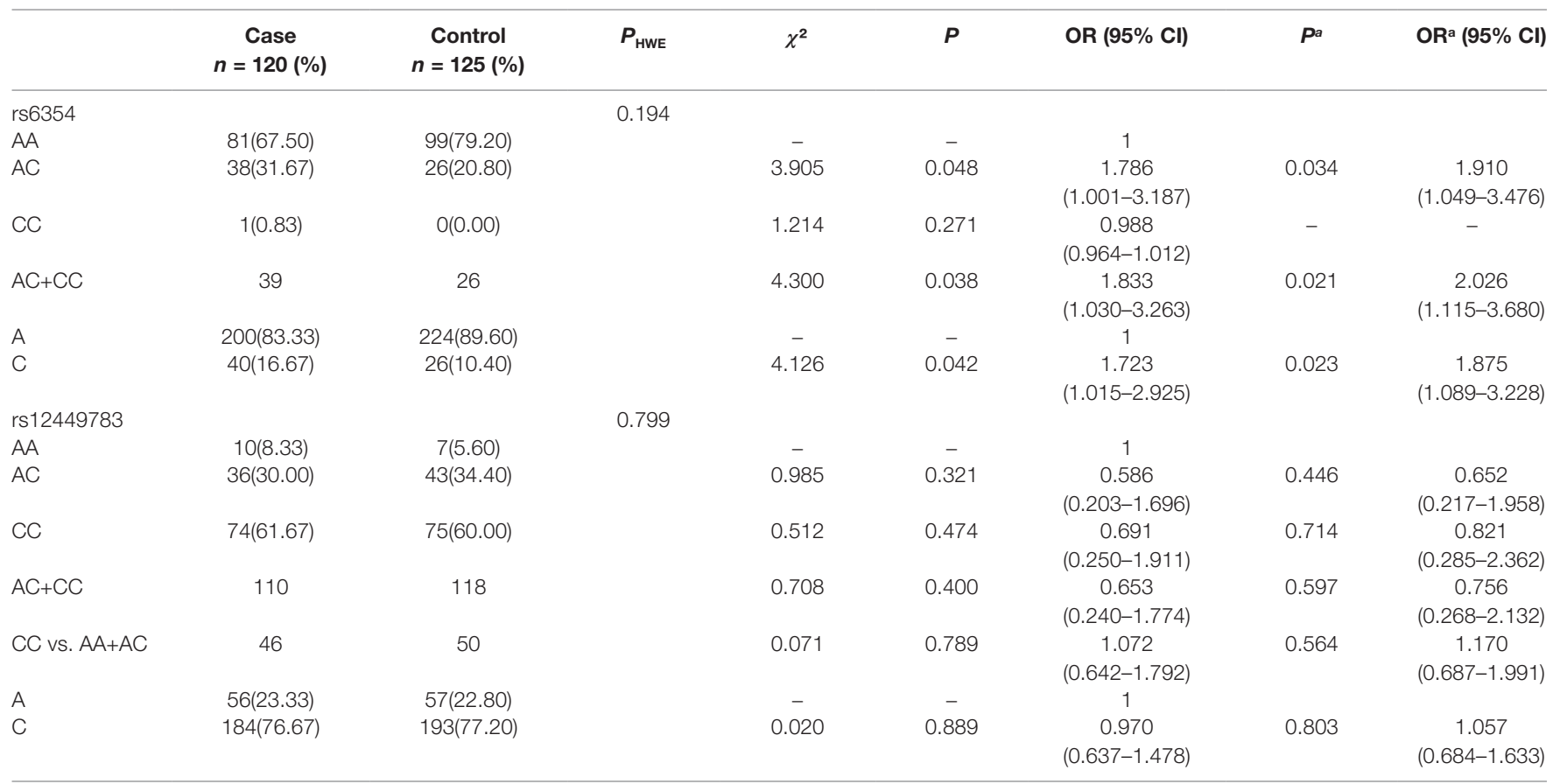

HWE, Hardy-Weinberg equilibrium; OR, odds ratio; $\mathrm{Cl}$, confidence interval.

athe values of $P$ and $O R$ were adjusted by age, gender and smoking. 

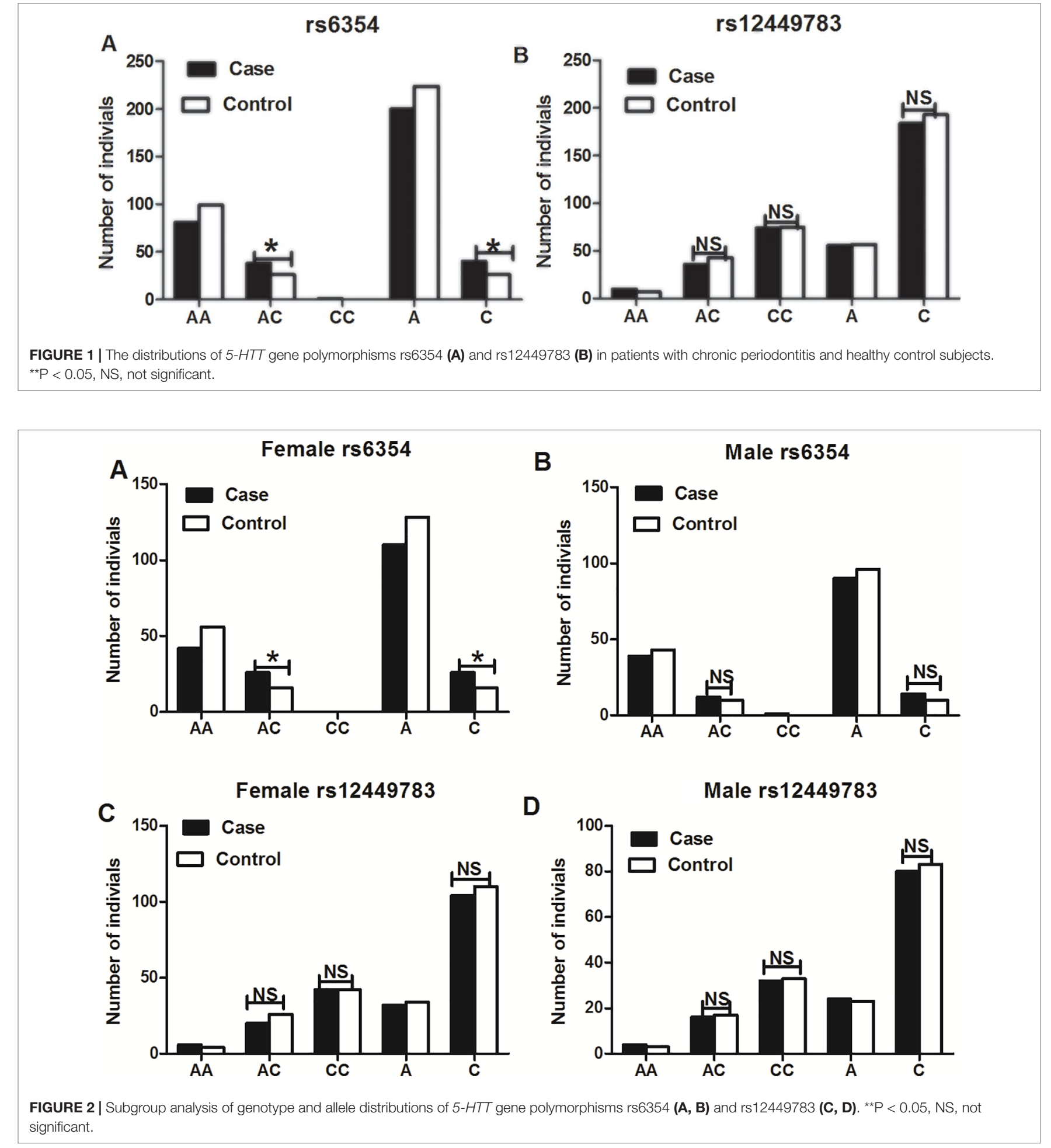

diseases (Slayton, 2006; Chaffee and Weston, 2010). Dental plaque is clearly an early step in the development of periodontal diseases, but many other factors are implicated in the progression of gingivitis to chronic periodontitis. Numerous studies have shown that susceptibility to periodontal diseases are affected by the polymorphisms of many genes, including interleukin-1 (IL-1)
(Boukortt et al., 2015), tumor necrosis factor- $\alpha$ (TNF- $\alpha$ ) (Heidari et al., 2013), transforming growth factor-beta (TGF $\beta$ ) and 5-HTT (Ozer Yucel et al., 2015).

5-HTT is a critical part of 5-HT transmission. Many studies have implicated in the etiology of neuropsychiatric disorders (Kuzelova et al., 2010; Borkowska et al., 2015). Recent research also 
TABLE 4 | Genotype and allele distributions of rs6354 and rs12449783 polymorphisms: subgroup analysis based on sex.

\begin{tabular}{|c|c|c|c|c|c|}
\hline & $\begin{array}{c}\text { Case } \\
n=120\end{array}$ & $\begin{array}{l}\text { Control } \\
n=125\end{array}$ & $\chi^{2}$ & $P$ & OR(95\% Cl) \\
\hline \multicolumn{6}{|l|}{ rs6354 } \\
\hline Females & $n=68(\%)$ & $n=72(\%)$ & & & \\
\hline AA & 42 (61.76) & 56 (77.78) & - & - & 1.000 \\
\hline $\mathrm{AC}$ & $26(38.24)$ & $16(22.22)$ & 4.270 & 0.039 & $\begin{array}{c}2.167 \\
(1.034-4.542)\end{array}$ \\
\hline $\mathrm{CC}$ & $0(0.00)$ & $0(0.00)$ & - & - & - \\
\hline$A$ & 110 (80.88) & 128 (88.89) & - & - & 1.000 \\
\hline $\mathrm{C}$ & 26 (19.12) & $16(11.11)$ & 3.517 & 0.061 & $\begin{array}{c}1.891 \\
(0.965-3.706)\end{array}$ \\
\hline Males & $n=52(\%)$ & $n=53(\%)$ & & & \\
\hline AA & 39 (75.00) & 43 (81.13) & - & - & 1.000 \\
\hline$A C$ & 12 (23.08) & $10(18.87)$ & 0.339 & 0.561 & $\begin{array}{c}1.323 \\
(0.515-3.402)\end{array}$ \\
\hline $\mathrm{CC}$ & $1(1.92)$ & $0(0.00)$ & 1.088 & 0.297 & $\begin{array}{c}1.026 \\
(0.976-1.078)\end{array}$ \\
\hline$A$ & 90 (86.54) & $96(90.57)$ & - & - & 1.000 \\
\hline $\mathrm{C}$ & $14(13.46)$ & $10(9.43)$ & 0.841 & 0.359 & $\begin{array}{c}1.493 \\
(0.631-3.531)\end{array}$ \\
\hline \multicolumn{6}{|c|}{ rs12449783 } \\
\hline Females & $n=68(\%)$ & $n=72(\%)$ & & & \\
\hline $\mathrm{AA}$ & $6(8.82)$ & $4(5.56)$ & - & - & 1.000 \\
\hline $\mathrm{AC}$ & $20(29.41)$ & $26(36.11)$ & 0.901 & 0.342 & $\begin{array}{c}0.513 \\
(0.127-2.065)\end{array}$ \\
\hline $\mathrm{CC}$ & $42(61.76)$ & 42 (58.33) & 0.358 & 0.550 & $\begin{array}{c}0.667 \\
(0.175-2.535)\end{array}$ \\
\hline$A$ & 32 (23.53) & 34 (23.61) & - & - & 1.000 \\
\hline $\mathrm{C}$ & $104(76.47)$ & 110 (76.39) & 0.000 & 0.987 & $\begin{array}{c}1.005 \\
(0.578-1.745)\end{array}$ \\
\hline Males & $n=52(\%)$ & $n=53(\%)$ & & & \\
\hline AA & 4 (7.69) & 3 (5.66) & - & - & 1.000 \\
\hline $\mathrm{AC}$ & $16(30.77)$ & 17 (32.08) & 0.173 & 0.677 & $\begin{array}{c}0.706 \\
(0.136-3.658)\end{array}$ \\
\hline $\mathrm{CC}$ & 32 (61.54) & 33 (62.26) & 0.158 & 0.691 & $\begin{array}{c}0.727 \\
(0.151-3.510)\end{array}$ \\
\hline$A$ & 24 (23.08) & $23(21.70)$ & - & - & 1.000 \\
\hline C & 80 (76.92) & $83(78.30)$ & 0.057 & 0.811 & $\begin{array}{c}0.924 \\
(0.483-1.768)\end{array}$ \\
\hline
\end{tabular}

TABLE 5 | Haplotype analysis of rs6354 and rs12449783 polymorphisms.

\begin{tabular}{|c|c|c|c|c|c|}
\hline \multirow[t]{2}{*}{ Rs6354-rs12449783 } & \multicolumn{2}{|c|}{ Haplotype (\%) } & \multirow[t]{2}{*}{$\chi^{2}$} & \multirow[t]{2}{*}{$P$} & \multirow[t]{2}{*}{ OR $(95 \% \mathrm{Cl})$} \\
\hline & Case & Control & & & \\
\hline$A-C$ & 159 (66.25) & $181(72.40)$ & - & - & Ref. \\
\hline C-A & $15(6.25)$ & $14(5.60)$ & 0.264 & 0.608 & $1.220(0.571-2.605)$ \\
\hline$A-A$ & $41(17.08)$ & $43(17.20)$ & 0.113 & 0.737 & $1.085(0.673-1.750)$ \\
\hline $\mathrm{C}-\mathrm{C}$ & $25(10.42)$ & $12(4.80)$ & 5.780 & 0.016 & $2.372(1.154-4.875)$ \\
\hline
\end{tabular}

implicated 5-HT in the pathogenesis of autoimmune and chronic inflammatory diseases (Tanaka et al., 2014). Polymorphisms of the gene could alter the expression and function of (Hariri et al., 2002). Two polymorphic regions of the gene have been identified: a $44 \mathrm{bp}$ insertion-deletion in the promoter region $(L P R)$ and a $17 \mathrm{bp}$ variable number of tandem repeat (VNTR) in the second intron (Lesch et al., 1994; Heils et al., 1996). The long (L) allele of LPR polymorphism increases 5-HT re-uptake (Greenberg et al., 1999), whereas the short (S) allele decreases the transcriptional efficiency of 5-HTT (Lesch et al., 1996). Multiple lines of evidence suggests that psychological factors also contribute in susceptibility to periodontal diseases (Goyal et al.,
2013; Graetz et al., 2013; Reshma et al., 2013; Delgado-Angulo et al., 2015). A study by Costa et al. suggests that the 5-HTT LPR polymorphism is a risk of aggressive periodontitis in a Brazilian population (Costa et al., 2008). No studies have examined the potential association between polymorphisms and periodontal diseases in a Chinese population.

The current study confirms the association between 5-HTT polymorphism and chronic periodontitis in the Chinese population. Specifically, the AC genotype, AC+CC genotype and $\mathrm{C}$ allele of the rs6354 polymorphism were more frequent in the subjects than in the healthy controls. Subgroup analysis suggested that women carrying the AC genotype of rs6354 have 
a higher risk of chronic periodontitis than women carrying other genotypes. A study by Su et al. indicated that rs6354 increases the risk of depressive symptoms (Su et al., 2009). Considering the notion that depression represents a risk factor of periodontal diseases (Hugo et al., 2006; Warren et al., 2014; Sundararajan et al., 2015), the association between rs6354 polymorphism and chronic periodontitis is reasonable. We did not find a significant association between the rs12449783 5-HTT polymorphism, but did show LD between rs6354 and rs12449783 and an increased risk of chronic periodontitis in subjects carrying the $\mathrm{C}-\mathrm{C}$ haplotype $\mathrm{C}-\mathrm{C}$. The interaction between the two 5-HTT SNPs requires further investigation.

The current study has several limitations. First, the sample size was relatively small for conducting subgroup analysis. Second, all study subjects were of Chinese Han ethnicity; whether the results could be extrapolated into other ethnic groups is unknown. Third, the results were adjusted only by age, sex and smoking status. Future studies with a larger sample size are needed to verify our findings.

In conclusion, 5-HTT rs6354 but not rs12449783 polymorphism is associated with a susceptibility to chronic periodontitis in the Chinese Han population. The interaction between the two SNPs also seems to be associated with chronic periodontitis.

\section{REFERENCES}

Armitage, G. C. (1999). Development of a classification system for periodontal diseases and conditions. Ann. Periodontol. 4 (1), 1-6. doi: 10.1902/ annals.1999.4.1.1

Bansal, M., Rastogi, S., and Vineeth, N. S. (2013). Influence of periodontal disease on systemic disease: inversion of a paradigm: a review. J. Med. Life 6 (2), 126-130.

Borkowska, A., Bielinski, M., Szczesny, W., Szwed, K., Tomaszewska, M., Kalwa, A., et al. (2015). Effect of the 5-HTTLPR polymorphism on affective temperament, depression and body mass index in obesity. J. Affect. Disord. 184, 193-197. doi: 10.1016/j.jad.2015.05.061

Boukortt, K. N., Saidi-Ouahrani, N., Boukerzaza, B., Ouhaibi-Djellouli, H., Hachmaoui, K., Benaissa, F. Z., et al. (2015). Association analysis of the IL-1 gene cluster polymorphisms with aggressive and chronic periodontitis in the Algerian population. Arch. Oral Biol. 60 (10), 1463-1470. doi: 10.1016/j. archoralbio.2015.06.018

Carinci, F., Scapoli, L., Girardi, A., Cura, F., Lauritano, D., Nardi, G. M., et al. (2013). Oral microflora and periodontal disease: new technology for diagnosis in dentistry. Ann. Stomatol. (Roma) 4 (2), 170-173.

Carrizales-Sepulveda, E. F., Ordaz-Farias, A., Vera-Pineda, R., and FloresRamirez, R. (2018). Periodontal disease, systemic inflammation and the risk of cardiovascular disease. Heart Lung Circ. 27 (11), 1327-1334. doi: 10.1016/j. hlc. 2018.05.102

Cengiz, M., Okutan, S. N., Bayoglu, B., Sakalli Kani, A., Bayar, R., and Kocabasoglu, N. (2015). Genetic polymorphism of the serotonin transporter gene, SLC6A4 rs16965628, is associated with obsessive compulsive disorder. Genet. Test Mol. Biomarkers 19 (5), 228-234. doi: 10.1089/gtmb.2014.0319

Chaffee, B. W., and Weston, S. J. (2010). Association between chronic periodontal disease and obesity: a systematic review and meta-analysis. J. Periodontol. 81 (12), 1708-1724. doi: 10.1902/jop.2010.100321

Chilmonczyk, Z., Bojarski, A. J., Pilc, A., and Sylte, I. (2015). Functional selectivity and antidepressant activity of serotonin 1A receptor ligands. Int. J. Mol. Sci. 16 (8), 18474-18506. doi: 10.3390/ijms160818474

Costa, J. E., Gomes, C. C., Cota, L. O., Pataro, A. L., Silva, J. F., Gomez, R. S., et al. (2008). Polymorphism in the promoter region of the gene for 5-HTT in individuals with aggressive periodontitis. J. Oral Sci. 50 (2), 193-198. doi: 10.2334/josnusd. 50.193

\section{DATA AVAILABILITY}

The datasets for this manuscript are not publicly available because of relevant national biological and biomedical regulations. Requests to access the datasets with pure academic use should be directed to the corresponding authors.

\section{ETHICS STATEMENT}

This study was reviewed and consented by the Ethics committee of Institute of Evidence-Based Medicine and Knowledge Translation, Henan University.

\section{AUTHOR CONTRIBUTIONS}

$\mathrm{X}-\mathrm{QR}, \mathrm{X}-\mathrm{TZ}$, and P-LG designed the study. LW and TD collected the data. X-QR and Y-YW examined data accuracy. C-YW and Y-YW performed the analysis. LW and X-TZ drafted the manuscript. P-LG reviewed the manuscript.

\section{FUNDING}

This work was supported by the health commission of Hubei Province Scientific Reserch Project (WJ2019H035).

Defrancesco, M., Liebaert, J., Kemmler, G., Aigner, F., Niederstatter, H., Parson, W., et al. (2013). Psychosocial state after bariatric surgery is associated with the serotonin-transporter promoter polymorphism. Eat. Weight Disord. 18 (3), 311-316. doi: 10.1007/s40519-013-0045-8

Delgado-Angulo, E. K., Sabbah, W., Suominen, A. L., Vehkalahti, M. M., Knuuttila, M., Partonen, T., et al. (2015). The association of depression and anxiety with dental caries and periodontal disease among Finnish adults. Community Dent. Oral Epidemiol. 43 (6), 540-549. doi: 10.1111/cdoe.12179

Divaris, K., Monda, K. L., North, K. E., Olshan, A. F., Reynolds, L. M., Hsueh, W. C., et al. (2013). Exploring the genetic basis of chronic periodontitis: a genome-wide association study. Hum. Mol. Genet. 22 (11), 2312-2324. doi: 10.1093/hmg/ddt065

Fann, J. C., Lai, H., Chiu, S. Y., Yen, A. M., Chen, S. L., and Chen, H. H. (2016). A population-based study on the association between the intake of soft drinks and periodontal disease in Taiwanese adults aged 35-44 years (KCIS no. 33). Public Health Nutr. 19 (8), 1471-1478. doi: 10.1017/S1368980015002608

Feuer, A. J., Demmer, R. T., Thai, A., and Vogiatzi, M. G. (2015). Use of selective serotonin reuptake inhibitors and bone mass in adolescents: an NHANES study. Bone 78, 28-33. doi: 10.1016/j.bone.2015.04.042

Galli, C., Macaluso, G., and Passeri, G. (2013). Serotonin: a novel bone mass controller may have implications for alveolar bone. J. Negat. Results Biomed. 12, 12. doi: 10.1186/1477-5751-12-12

Goyal, S., Gupta, G., Thomas, B., Bhat, K. M., and Bhat, G. S. (2013). Stress and periodontal disease: the link and logic!! Ind. Psychiatry J. 22 (1), 4-11. doi: 10.4103/0972-6748.123585

Graetz, C., Ehrenthal, J. C., Senf, D., Semar, K., Herzog, W., and Dorfer, C. E. (2013). Influence of psychological attachment patterns on periodontal disease a pilot study with 310 compliant patients. J. Clin. Periodontol. 40 (12), 10871094. doi: $10.1111 /$ jcpe. 12159

Greenberg, B. D., Tolliver, T. J., Huang, S. J., Li, Q., Bengel, D., and Murphy, D. L. (1999). Genetic variation in the serotonin transporter promoter region affects serotonin uptake in human blood platelets. Am. J. Med. Genet. 88 (1), 83-87. doi: 10.1002/(SICI)1096-8628(19990205)88:1<83::AID-AJMG15>3.0.CO;2-0

Hariri, A. R., Mattay, V. S., Tessitore, A., Kolachana, B., Fera, F., Goldman, D., et al. (2002). Serotonin transporter genetic variation and the response of the human amygdala. Science 297 (5580), 400-403. doi: 10.1126/science.1071829

Heidari, Z., Mahmoudzadeh-Sagheb, H., Rigi-Ladiz, M. A., Taheri, M., MoazenniRoodi, A., and Hashemi, M. (2013). Association of TGF-betal -509 C/T, 29 
$\mathrm{C} / \mathrm{T}$ and $788 \mathrm{C} / \mathrm{T}$ gene polymorphisms with chronic periodontitis: a casecontrol study. Gene 518 (2), 330-334. doi: 10.1016/j.gene.2012.12.108

Heils, A., Teufel, A., Petri, S., Stober, G., Riederer, P., Bengel, D., et al. (1996). Allelic variation of human serotonin transporter gene expression. J. Neurochem. 66 (6), 2621-2624. doi: 10.1046/j.1471-4159.1996.66062621.x

Ho, P. S., Ho, K. K., Huang, W. S., Yen, C. H., Shih, M. C., Shen, L. H., et al. (2013). Association study of serotonin transporter availability and SLC6A4 gene polymorphisms in patients with major depression. Psychiatry Res. 212 (3), 216-222. doi: 10.1016/j.pscychresns.2012.04.005

Hugo, F. N., Hilgert, J. B., Bozzetti, M. C., Bandeira, D. R., Goncalves, T. R., Pawlowski, J., et al. (2006). Chronic stress, depression, and cortisol levels as risk indicators of elevated plaque and gingivitis levels in individuals aged 50 years and older. J. Periodontol. 77 (6), 1008-1014. doi: 10.1902/jop.2006.050037

Jin, L. J., Armitage, G. C., Klinge, B., Lang, N. P., Tonetti, M., and Williams, R. C. (2011). Global oral health inequalities: task group-periodontal disease. Adv. Dent. Res. 23 (2), 221-226. doi: 10.1177/0022034511402080

Kuzelova, H., Ptacek, R., and Macek, M. (2010). The serotonin transporter gene (5-HTT) variant and psychiatric disorders: review of current literature. Neuro Endocrinol. Lett. 31 (1), 4-10.

Lee, S. I., Lee, D. W., Yun, H. M., Cha, H. J., Bae, C. H., Cho, E. S., et al. (2015). Expression of thymosin beta- 4 in human periodontal ligament cells and mouse periodontal tissue and its role in osteoblastic/cementoblastic differentiation. Differentiation 90 (1-3), 16-26. doi: 10.1016/j.diff.2015.08.003

Lesch, K. P., Balling, U., Gross, J., Strauss, K., Wolozin, B. L., Murphy, D. L., et al. (1994). Organization of the human serotonin transporter gene. J. Neural Transm. Gen. Sect. 95 (2), 157-162. doi: 10.1007/BF01276434

Lesch, K. P., Bengel, D., Heils, A., Sabol, S. Z., Greenberg, B. D., Petri, S., et al. (1996). Association of anxiety-related traits with a polymorphism in the serotonin transporter gene regulatory region. Science 274 (5292), 1527-1531. doi: 10.1126/science.274.5292.1527

Ma, Y., Li, B., Wang, C., Zhang, W., Rao, Y., and Han, S. (2015). Allelic variation in 5-HTTLPR and the effects of citalopram on the emotional neural network. $\mathrm{Br}$. J. Psychiatry 206 (5), 385-392. doi: 10.1192/bjp.bp.114.150128

Meyle, J., and Chapple, I. (2015). Molecular aspects of the pathogenesis of periodontitis. Periodontol. 200069 (1), 7-17. doi: 10.1111/prd.12104

Nagpal, R., Yamashiro, Y., and Izumi, Y. (2015). The two-way association of periodontal infection with systemic disorders: an overview. Mediators Inflamm. 2015, 793898. doi: 10.1155/2015/793898

Ozer Yucel, O., Berker, E., Mesci, L., Eratalay, K., Tepe, E., and Tezcan, I. (2015). Analysis of TNF-alpha (-308) polymorphism and gingival crevicular fluid TNF-alpha levels in aggressive and chronic periodontitis: a preliminary report. Cytokine 72 (2), 173-177. doi: 10.1016/j.cyto.2015.01.001
Reshma, A. P., Arunachalam, R., Pillai, J. K., Kurra, S. B., Varkey, V. K., and Prince, M. J. (2013). Chromogranin A: novel biomarker between periodontal disease and psychosocial stress. J. Indian Soc. Periodontol. 17 (2), 214-218. doi: 10.4103/0972-124X.113076

Silva, N., Abusleme, L., Bravo, D., Dutzan, N., Garcia-Sesnich, J., Vernal, R., et al. (2015). Host response mechanisms in periodontal diseases. J. Appl. Oral Sci. 23 (3), 329-355. doi: 10.1590/1678-775720140259

Slayton, R. L. (2006). Genetics and environmental factors play important roles in the risk for periodontal disease and edentulism. J. Evid. Based Dent. Pract. 6 (3), 238-239. doi: 10.1016/j.jebdp.2006.06.011

Su, S., Zhao, J., Bremner, J. D., Miller, A. H., Tang, W., Bouzyk, M., et al. (2009). Serotonin transporter gene, depressive symptoms, and interleukin-6. Circ. Cardiovasc. Genet. 2 (6), 614-620. doi: 10.1161/CIRCGENETICS.109.870386

Sundararajan, S., Muthukumar, S., and Rao, S. R. (2015). Relationship between depression and chronic periodontitis. J. Indian Soc. Periodontol. 19 (3), 294296. doi: 10.4103/0972-124X.153479

Tanaka, T., Doe, J. M., Horstmann, S. A., Ahmad, S., Ahmad, A., Min, S. J., et al. (2014). Neuroendocrine signaling the serotonin transporter regulates clearance of apoptotic cells. J. Biol. Chem. 289 (15), 10466-10475. doi: 10.1074/ jbc.M113.482299

Thyvalikakath, T. P., Padman, R., Vyawahare, K., Darade, P., and Paranjape, R. (2015). Utilizing dental electronic health records data to predict risk for periodontal disease. Stud. Health Technol. Inform. 216, 1081.

Tollenaar, M. S., Molendijk, M. L., Penninx, B., Milaneschi, Y., and Antypa, N. (2017). The association of childhood maltreatment with depression and anxiety is not moderated by the oxytocin receptor gene. Eur. Arch. Psychiatry Clin. Neurosci. 267 (6), 517-526. doi: 10.1007/s00406-017-0784-z

Warren, K. R., Postolache, T. T., Groer, M. E., Pinjari, O., Kelly, D. L., and Reynolds, M. A. (2014). Role of chronic stress and depression in periodontal diseases. Periodontol. 200064 (1), 127-138. doi: 10.1111/prd.12036

Conflict of Interest Statement: The authors declare that the research was conducted in the absence of any commercial or financial relationships that could be construed as a potential conflict of interest.

Copyright (c) 2019 Wu, Deng, Wang, Ren, Wang, Zeng and Geng. This is an openaccess article distributed under the terms of the Creative Commons Attribution License (CC BY). The use, distribution or reproduction in other forums is permitted, provided the original author(s) and the copyright owner(s) are credited and that the original publication in this journal is cited, in accordance with accepted academic practice. No use, distribution or reproduction is permitted which does not comply with these terms. 